\title{
REVISED Growth in floor area: the blind spot in cutting carbon
}

\section{[version 2; peer review: 3 approved]}

\author{
David Ness (iD
}

School of Natural and Built Environments, University of South Australia, Adelaide, South Australia, 5000, Australia

V2 First published: 24 Jan 2020, 2:2

https://doi.org/10.35241/emeraldopenres.13420.1

Second version: 09 Mar 2020, 2:2

https://doi.org/10.35241/emeraldopenres.13420.2

Latest published: $22 \mathrm{Apr} 2020,2: 2$

https://doi.org/10.35241/emeraldopenres.13420.3

\section{Abstract}

While most efforts to combat climate change are focussed on energy efficiency and substitution of fossil fuels, growth in the built environment remains largely unquestioned. Given the current climate emergency and increasing scarcity of global resources, it is imperative that we address this 'blind spot' by finding ways to support required services with less resource consumption.

There is now long overdue recognition to greenhouse gas emissions 'embodied' in the production of building materials and construction, and its importance in reaching targets of net zero carbon by 2050. However, there is a widespread belief that we can continue to 'build big', provided we incorporate energy saving measures and select 'low carbon materials' - ignoring the fact that excessive volume and area of buildings may outweigh any carbon savings. This is especially the case with commercial real estate.

As the inception and planning phases of projects offer most potential for reduction in both operational and embodied carbon, we must turn our attention to previously overlooked options such as 'build nothing' or 'build less'. This involves challenging the root cause of the need, exploring alternative approaches to meet desired outcomes, and maximising the use of existing assets. If new build is required, this should be designed for adaptability, with increased stewardship, so the building stock of the future will be a more valuable and useable resource.

This points to the need for increased understanding and application of the principles of strategic asset management, hitherto largely ignored in sustainability circles, which emphasize a close alignment of assets with the services they support.

Arguably, as the built environment consumes more material resources and energy than any other sector, its future configuration may be critical to the future of people and the planet. In this regard, this paper seeks to break new ground for deeper exploration.

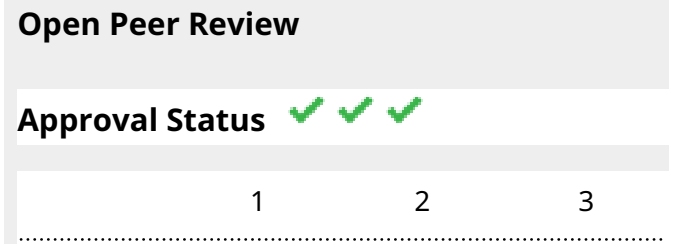

version 3

(revision)

22 Apr 2020

version 2

(revision)

09 Mar 2020

version 1

24 Jan 2020
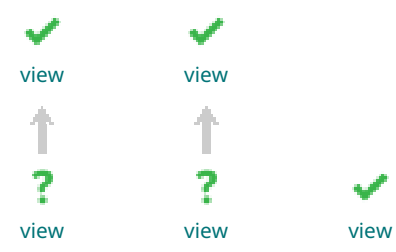

1. Petter Naess, Norwegian University of Life Sciences, Ås, Norway

2. Gang Liu (iD, Central South University, Changsha, Peoples Republic Of China

3. Francesco Pomponi ID, Edinburgh Napier University, Edinburgh, United Kingdom Bernardino D'Amico ID, Edinburgh Napier University, Edinburgh, United Kingdom Jay Arehart iD, University of Colorado, Boulder, United States

Edinburgh Napier University, Edinburgh, United Kingdom

Any reports and responses or comments on the article can be found at the end of the article. 


\section{Keywords}

Strategic asset management, service demand, embodied carbon, building stock management, over-consumption, commercial real estate, China

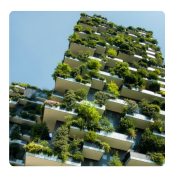

This article is included in the Sustainable Cities gateway.

Corresponding author: David Ness (david.ness@unisa.edu.au)

Author roles: Ness D: Conceptualization, Formal Analysis, Investigation, Methodology, Resources, Validation, Visualization, Writing Original Draft Preparation, Writing - Review \& Editing

Competing interests: Authorship of the book 'The impact of overbuilding on people and planet' (Ness 2019a), which may lead to royalty payments, is declared.

Grant information: While no grants were involved in supporting this work, the author acknowledges that ARUP provided funds under the ARUP Global Research Challenge 2017 for the ARUP-UniSA research, to which reference is made (ARUP 2018).

Copyright: $\odot 2020$ Ness D. This is an open access article distributed under the terms of the Creative Commons Attribution License, which permits unrestricted use, distribution, and reproduction in any medium, provided the original work is properly cited.

How to cite this article: Ness D. Growth in floor area: the blind spot in cutting carbon [version 2; peer review: 3 approved]

Emerald Open Research 2020, 2:2 https://doi.org/10.35241/emeraldopenres.13420.2

First published: 24 Jan 2020, 2:2 https://doi.org/10.35241/emeraldopenres.13420.1 


\section{REVISED Amendments from Version 1}

This version includes improvements suggested by the Reviewers, including: mention of the causes of the blind spot i.e. the growth imperative within the current economic system, with particular reference to the impact of capitalist property expansion (Van Griethuysen, 2012); the limitations of build nothing and build less have been acknowledged in 'Concluding remarks' i.e. at odds with capitalist property expansion; the advocation of strategic asset management is qualified by reference to possible negative effects of profitability ambitions; reference has been made to rebound effects and the work of Santarius et al. (2016); transportation impacts of growth in floor space per capita have been added; corrections made within Box 1 to differentiate residential and commercial floor areas; Under 'The service or performance economy', the meaning of services has been explained i.e. community services etc, which links to the later reference to socio-ecological services; in that regard, the field of ecological economics is explicitly acknowledged as providing a framework in 'A way forward': policies and mechanisms', with reference to Kallis et al. (2012); Morgan (2017) and Van Griethuysen (2012); that section is also more closely linked to the following section i.e. Concluding remarks; the earlier section heading 'A way forward' has been changed to 'Stronger intervention needed'; 'Concluding remarks' now mention how emerging economies might approach asset and infrastructure requirements to achieve sustainability goals; minor language corrections.

Any further responses from the reviewers can be found at the end of the article

\section{Introduction}

As the world's population approaches 10 billion, the global building stock is projected to double in size (WGBC, 2019a). By 2060, more than 230 billion square metres of floor area are expected to be added to the planet in new buildings construction, "equivalent to building the current floor area of Japan every single year from now until 2060" (UNE, IEA, 2017, p. 13). Architecture 2030 (2020a) compared this to adding an entire New York City to the planet every 34 days for the next 40 years. However, due to urban growth, with 1.5 million people added to cities every week, it is generally taken for granted that we must build that amount of space to meet their needs for housing and urban services, offices, education, health and transport facilities.

At the same time, it is widely recognised that the building and construction sector, encompassing buildings and infrastructure, is responsible for 39\% of global greenhouse gas (GHG) emissions and $40 \%$ of resource consumption - the largest of any sector (EMF, 2019). Thus far, efforts to reduce carbon have concentrated on energy-efficiency of operational systems, such as heating, cooling and lighting, which are responsible for about $28 \%$ of global emissions. More recently, driven by the "climate emergency' and pursuit of net zero carbon, attention is now shifting to the $11 \%$ carbon 'embodied' in construction materials and processes - forecast to form half of all building related emissions by 2050. Along with savings in operational carbon, reducing this embodied carbon is now seen as imperative to reach net zero carbon by 2050 (WGBC, 2019a).

However, given the scale of the global challenges, current international programs, actions and research - within building, urban development and beyond - do not go far enough. They rely heavily upon a belief in the decoupling of economic growth from environmental impact, and a nexus between 'better growth, better climate' (NCE, 2014). This is reflected in the key building and construction sector, where efforts to cut carbon are concentrated on increased material and energy efficiency.

Whilst they may achieve some gains, such efforts are not meeting targets and may be merely 'playing around the edges.' They are likely to be outweighed by the sheer size and mass of the built environment and all the materials (and energy) it consumes. Arguably, attention should shift to bigger and more fundamental challenges, such as tackling material demand and consumption at its source. Do we really need 230 billion square metres of additional floor space to meet future needs? Is there a way to satisfy community service demands with reduced consumption of material (and other) resources - in a smaller and smarter manner? Should such demands be more closely scrutinized in the first place, with genuine needs distinguished from wants, with options for meeting these explored and compared before a physical project even exists? Should we seek, in the developed world, to reduce the material flow in our industrialized but highly consuming cities to enable those in the developing world to grow?

These are some of the great challenges of our time, which demand that we lift our sights and consider radical, alternative strategies. By 'turning current approaches on their head', we may be able to reduce both operational and embodied carbon, and potentially offer a more effective and direct route to grapple with global emissions at their source. Whilst there is a surfeit of literature in this area, various authors have argued for increased attention to 'sufficiency', less material intensive growth, and even - more controversially - 'degrowth'. Moreover, when accompanied by a rebalancing between rich and poor, reduction in service demand has been viewed as "the gold medal of environmentally motivated materials management" (Allwood, 2014, p. 450). Whilst it may pose an Olympian challenge, this forms a key proposition of this paper.

It seeks to answer these questions by applying the principles and theory of strategic asset management, where physical assets are viewed in terms of supporting service outcomes. Literature on the topic of reducing emissions and resource consumption in the built environment, including contemporary thinking, is critically examined. Using 'philosophical conceptualization', works on the same topic are analysed, their common elements summarised, and differences compared, with a view to creating fresh insights.

Commercial real estate (CRE) and infrastructure have been identified as bearing the greatest responsibility for consumption and emissions (University of Cambridge, 2014). Although the stock of infrastructure is expected to double shortly after 2030, largely due to the pressing needs of the global south (NCE, 2018), this paper focuses upon buildings and especially CRE - where current trends are especially extravagant and wasteful. In this regard, Van Griethuysen (2012, p. 264) understood "the growth imperative" within the current economic system as "a consequence of capitalist property expansion", bringing increased riches for proprietors. Accordingly, the growth of floor area in CRE and in China are used to illustrate the magnitude of the challenges, to examine how these may be addressed using 
theory and practical mechanisms, and to identify further work required.

\section{The challenge: carbon cuts "not on track"}

Global targets forming part of the Paris accord, though, are not being met - including those for the built environment. Harvey \& Rankin (2019) reported that emissions for 2019 would be $4 \%$ higher than those in 2015 , noting that fundamental societal change and more ambitious targets are required. As the World Green Building Council (WGBC, 2019b) has urged, a big step-up in tackling emissions is necessary.

While recognising that the built environment may have "potential for huge emission cuts", the 2019 Global Status Report states that the sector "is not on track with the level of climate action necessary". Emissions from buildings are set to double by 2050 , rather than drop, due to a slowdown in efficiency gains - hence not enough to outpace growth - and a growing need for floor space around the world (GlobalABC et al., 2019, pp. 3,9):

"Global building sector emissions increased 2\% from 2017 to 2018 , to reach a record high...Growth was driven by strong floor space and population expansions that led to a $1 \%$ increase in energy consumption...".

While accepting that "the building stock is set to double by 2050", the authors (somewhat optimistically) see this as "another important opportunity not to be missed". Again, they place their faith in energy efficiency measures: "we have to double our efforts on energy efficiency to bring gains of at least $3 \%$ per year." On the other hand, as shown in Figure 1, growth in energy consumption was attributed primarily to growth in floor area and population.

According to the Global Status Report (GlobalABC et al., 2019, p. 14):

"Final energy consumption in residential buildings made up more than $70 \%$ of the grand total in 2018, with growth resulting primarily from floor area and population increases, while floor area alone remains the main driver of higher consumption in non-residential buildings."

Alarmingly, as shown in Figure 1, growth in floor area surpasses growth in population. The reason can be found in the 2016 Report, which emphasized that "consumption is the main driver of material use, more important than population growth in recent decades" (UNEP, 2016, p. 5). Furthermore, floor space has grown worldwide by $23 \%$ since 2010, and by $3 \%$ since 2017 .

While wringing their hands with concern that:

"Strong floor area and population expansions continue to raise buildings sector energy use: building envelopes and systems have not improved enough to offset this growth."

the authors of the 2019 Report sidestep the issue by proclaiming "improvements in energy use are helping offset big growth of new building" (GlobalABC et al., 2019, p. 15). Should not efforts also be made to constrain the excessive growth in floor area, especially in the residential and commercial sectors?

There is another less obvious impact of growth in per capita floor area. The higher this becomes, the longer will be the distance between residences, jobs and service facilities - leading to increased energy and carbon for connecting motorized transportation. This may counteract resource-saving principles in urban planning (Naess, 2016).

If the world, and especially the already industrialised nations, continue to build so extravagantly and at such a rate, global ambitions to attain net zero by 2050 will almost certainly be jeopardised. As Yan (2018) has highlighted (Box 1), it is necessary to constrain growth in floor area if significant cuts are to be made to emissions. In other words, we need to reduce excessive consumption. China has the fastest growth in built environment floor area in the world, so will assume centre stage in any moves to address this challenge (Figure 2).

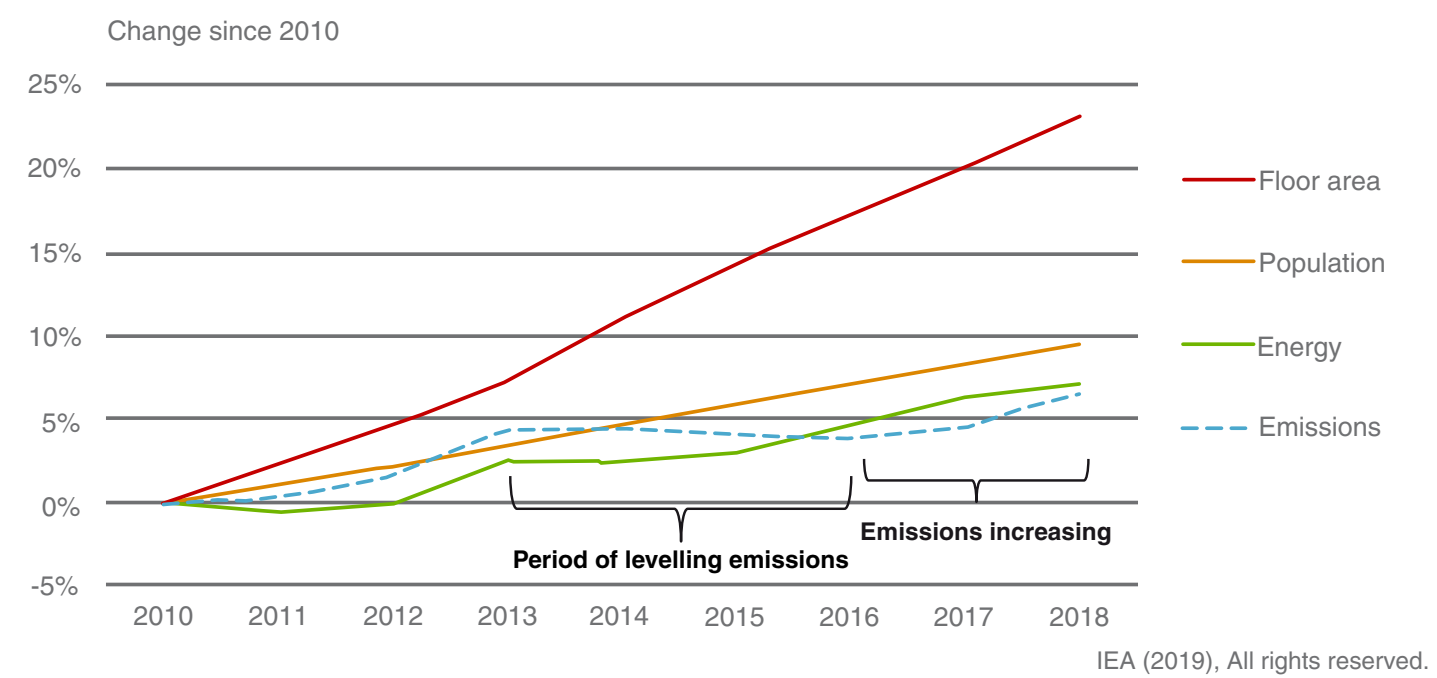

Figure 1. Changes in floor area, population, buildings sector energy use and energy related emissions globally. Source: GlobalABC et al. (2019, p. 9). 


\section{Box 1. Growth in floor area in China}

Yan (2018) is among the few to have studied the impact of growth in floor area on energy use and emissions reduction. He reported that China's new annually completed buildings were around 1.5 billion square metres in 2001, which rose to 2.6 billion in 2016. Among those constructed in 2016, about $66 \%$ were residential. China's total floor area in 2016 was approximately 58.3 billion square metres. The residential floor area per capita was 28.9 square metres in urban areas and 40.4 square metres in rural areas compared with about 50 square metres per capita in US, Canada and Australia. He also explained that the average commercial floor area per capita in China was 8.5 square metres, compared with 25 square metres in the US The increased building floor area led to increased demand for building materials, with cement and steel being the highest. Embodied energy associated with construction of buildings and infrastructure accounted for $25 \%$ of China's total primary energy consumption.

This analysis by Yan (2018) is reinforced by Jiang et al. (2019). China drives up to $30 \%$ of global material use. Capital formation, particularly buildings and infrastructure, is responsible for 50 $86 \%$ of this and drives $62 \%$ of China's fossil fuel footprint. This is important because the production of materials for infrastructure construction, such as cement and steel, is generally harder to decarbonise than other sectors. The authors added that it is essential to produce capital stock as resource-efficiently as possible and, more importantly, to begin to design it now for circularity.

Yan (2018) went further, highlighting the extent and consequences of the massive growth in floor space:

"If the floor area keeps increasing in the next 15 years, the total building floor area in China may be more than 100 billion (square metres), which is not affordable in energy and environment."

With suitable policy measures, he believed the total floor area could be controlled under 80 billion square metres. This scenario was affordable for energy and the environment, and possible to support improvement in living standards and economic development. Moreover, of major significance for China and global policies, "the control of floor area may reduce about $75 \%$ of energy use for materials used in building construction (italics added)."

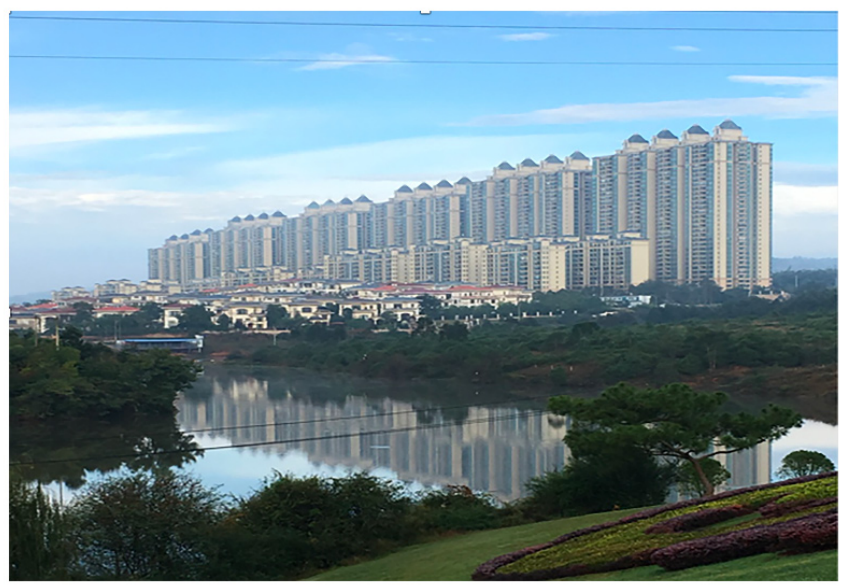

Figure 2. A phalanx of apartments, China. Reproduced courtesy of Anne Stevenson-Yang, J. Capital Research.

\section{Increased resource efficiency not enough}

The International Resource Panel (IRP, 2018) report on 'the weight of cities' highlights the challenges of urbanisation, rising from $54 \%$ in 2015 to $66 \%$ in 2050 . Beginning to grapple with the challenge of overconsumption, it proposes a domestic material consumption range of 6-8 tonnes per capita as an indicative target for sustainable consumption, a $50 \%$ reduction from the present 6-17 tonnes per capita. Disappointingly, the IRP bases its recommendations on increased resource efficiency, which will not dramatically reduce the weight.

Similarly, the New Urban Agenda (UN, 2017), New Climate Economy (NCE, 2014; NCE, 2016; NCE, 2018) and the World Resources Institute (WRI, 2020) all appear wedded to a belief in resource efficient and circular growth, with no trade-off required between growth and strong climate action. In other words, we can have our net zero carbon growth cake and consume it too! Raising resource efficiency and resource productivity are seen to be "at the heart of both growth and emissions reduction" (NCE, 2014 , p. 6). In this regard, energy efficiency is once more relied upon to meet a significant proportion of the necessary climate action - even more than renewables (Floater et al., 2014).

Optimistically, the 'new growth agenda' recognises that the objectives of growth, climate action and development are interrelated and complementary. At the core of this agenda are "liveable, inclusive and compact cities which have an economic dynamism that can attract creative talent, companies and capital....", while "powering this new story will be affordable, clean energy systems" (NCE, 2018, p. 21).

Meanwhile, the circular economy (CE) is seen as able to "radically reduce demand for energy-intensive primary materials, driving up material productivity and cutting waste." According to the Ellen MacArthur Foundation (EMF, 2019), the CE can "complete the picture" in tackling climate change and represents a fundamental shift in the global approach to cutting emissions. While moving to renewables can address $55 \%$ of global GHG emissions, "it is imperative to tackle the remaining $45 \%$ to meet UN climate goals". Concentrating on materials such as cement, plastics, steel and aluminium, the EMF argues that designing out waste and keeping materials in use can dramatically reduce emissions. It can "optimise decarbonisation and economic development in mutual support of each other" (EMF, 2019). In other words, like resource efficiency, the $\mathrm{CE}$ is seen as an instrument to support increased consumption-driven economic growth.

In buildings, transport and industry sectors, energy efficiency is widely seen as critical to meet global targets, including retrofitting existing infrastructure. Otherwise, "continued population growth and economic development is expected to lead to a $60 \%$ increase in energy demand by 2050" (NCE, 2018, p. 49). Approaches towards a net zero carbon-built environment have, until now, presumed that increased growth, including material growth, can be enabled by increased resource and energy efficiency - coupled with CE approaches and technological fixes (Victor et al., 2019): the panacea to accelerating the transition to a low carbon future. 
The NCE $(2018,11)$ assured us that increased energy efficiency within a $\mathrm{CE}$ "could decouple economic growth from material use and drive decarbonisation...". UNEP (2016, p. 5), on the other hand, warned that "in order to be successful, decoupling efforts need to go beyond simple efficiency gains...." In this regard, Santarius et al. (2016, p. 2) have highlighted the "systemic relationship between efficiency and expansion", whereby efficiency improvement may lead to an increase in demand - "the rebound effect'. Decoupling is not possible if rebound effects continue to be unrecognised and unchecked.

\section{From a circular to a 'sufficiency' economy}

A circular approach alone is unlikely to be effective in decoupling growth from resource use, as demonstrated by insightful analysts such as Skene (2018) and Giampietro (2019). Millar et al. (2019, p. 15) expressed this most succinctly: "if demand is growing, the circle cannot remain closed", while De Decker (2018) added that the CE concept "only focuses on a small part of total resource use and does not take into account the laws of thermodynamics". Global resource use - both energetic and material - keeps increasing year by year, "more than double the rate of population growth". Growth makes a CE impossible:

"The amount of used materials that can be reused or recycled will always be smaller than the material needed for growth.

To compensate for that, we have to continuously extract more resources."

According to the second law of thermodynamics, the quality of energy diminishes when it is transferred or transformed. Recycling or reuse also require energy, both in the recycling process or transportation of recycled or reused materials.

In his concept of a CE, Stahel (2008); Stahel (2010) emphasized the importance of stewardship of existing capital, natural and human stocks, management of physical assets over time, and advocated 'Sufficiency', using less resources. This theme was developed by Bocken \& Short (2020, p. 2) who suggested:

“... a need to move from a consumption-oriented society towards a society based, not only on circular economy, but on 'sufficiency', or in other words, a transition to a society where we can manage with (in some cases much) less."

To be effective, a CE would demand that we not only use less fossil fuels but also accumulate less raw materials in commodities and stock. Consistent with messages from Allwood (2014) and the University of Cambridge (2014), including their call for fairer distribution of resources, De Decker (2018) argued that "we need to make less stuff", including fewer buildings. In other words, to use less materials, much less.

\section{Need for absolute reductions in material use}

More efficient growth can lead to a false sense of security, when absolute reductions in energy and material throughput are required. Similarly, greater material efficiency is not enough, because "new buildings, no matter how green, still add to the total human load" (Rees, 2009, p. 309). As Moffatt \& Russell (2001) pointed out, "the most environmentally benign building is the one that does not have to be built".
However, the building and property sector has been able to operate in a profligate manner and 'build big', consuming substantial amounts of material resources, while claiming to be 'green'. Rees (2009) drew attention to this disturbing trend: while the average US household size fell from 3.7 to 2.6 people between 1950 and 2003, floor space per capita increased by over $230 \%$. He observed $(2009,304)$ :

"Most mainstream approaches to sustainability today hybrid cars, green buildings, smart growth, the new urbanism, green consumerism - do not, in fact, address the fundamental problem. Instead, they attempt to reproduce the status quo by other means...today's global society essentially equates sustainability with maintaining growth through technological innovation and greater material and economic efficiency."

In tackling this fundamental problem, and making a significant cut in construction emissions, the 'Use Less Group' claims the most effective way is to use less material, while making buildings that last much longer (University of Cambridge, 2014). In theory, meeting service needs with half as much material, and keeping it for twice as long, may reduce material consumption and associated emissions to about a quarter (Allwood et al., 2017, p. 5). This is similar thinking to Von Weizsäcker et al. (1997), who argued for a Factor 4 change in resource productivity via halving material consumption and doubling prosperity, while Schmidt-Bleek (2000) aimed for Factor 10. It is important to note, as Naess (2006) pointed out, that the original Factor 10 objectives referred to an "absolute reduction" in environmental load and resource consumption. This was later modified by "green capitalism" proponents who referred to the reduction in terms of per produced unit.

Increasing recognition of embodied carbon as part of 'consumption-based emissions' (Scope 3) can throw resource consumption into sharper focus (C40 Cities, 2019; WRI et al., 2015); put simply, if less material resources are consumed, then embodied carbon will be reduced.

\section{Embodied carbon: can it signal a change of direction?}

Embodied or 'capital' carbon has flown under the international radar for many years, with most attention concentrated on reducing operational energy and carbon. However, this is now attracting wide attention, as demonstrated by the WGBC (2019a) report: 'Bringing embodied carbon upfront'. This establishes a vision for net zero operational and $40 \%$ less embodied emissions by 2030 , with net zero operational and embodied emissions by 2050 .

However, in responding to the challenge posed by the massive growth in building stock, green and sustainable building organizations tend to be fixated on building more efficiently and cleverly, such as via use of low carbon materials and new technologies. The Carbon Leadership Forum (2020) and its Embodied Carbon Network at the University of Washington, for example, claim that "reducing the carbon emissions of materials is an imperative". While the 'Zero Code' of Architecture 2030 (2018) has ambitious goals, these focus on ensuring energy efficiency is "locked into" new building stock; embodied carbon 
is covered by a "carbon smart materials palette" (Architecture 2030, 2020b). Although LEED 4.1 advocates reuse of existing resources during initial project decision-making and reduced materials use (Hughes, 2019), green building rating tools in the US and elsewhere tend to place most emphasis on awarding more credits within their 'materials and resources' categories. But this misses the point. Restraining the size and extravagance of new buildings, it seems, does not form part of the agenda.

Turning to Australia, the Green Building Council and Property Council (GBCA \& PCA, 2019) have launched a "practical plan for emissions reduction" that includes (Recommendation 7.2) a "net zero embodied carbon strategy", to include baselines, timeline with targets, and "embodied carbon disclosure" for large public projects. However, once again, this topic is relegated to the theme "transform markets for materials and products". Moreover, despite claims that Australia is 'stepping up' to decarbonise, the GBCA target to reduce embodied carbon in new buildings (except residential) by $10 \%$ from 2020 falls short of C40 Cities and WGBC ambitions (Chapa, 2019; GBCA, 2018). In addition, "new buildings will be incentivised to offset their embodied carbon and other emissions" - contrary to advice from the WRI (2020) and others, where 'carbon reduction' is preferred to 'carbon offsets' (a last resort).

While the selection of low embodied carbon materials and new technologies may achieve up to $50 \%$ carbon reduction, this may be outweighed by the sheer size of buildings and all the materials (and energy) they consume. It may be merely 'playing around the edges', while pandering to the protagonists of so-called 'resource efficient growth'. As the 'Use Less Group' (2020) has highlighted: "The demand for materials in construction is driven by the rate at which we expand our total stock of buildings" (in other words, by growth in floor area), also their rate of replacement and, lastly (not firstly), the selection and use of materials.

Therefore, it is time to join the main game, to grasp the opportunity for strategic decisions such as 'build nothing' or 'build less', where most carbon savings can be made. This is explained in the next section.

\section{Tackling capital carbon - and doing it early}

HM Treasury (2013, p. 11) and the Green Construction Board (2013, p. 4) recognised that growth in demand for new building stock and investment in refurbishment, together with infrastructure development, "have a significant impact on capital carbon"; they argued this should be addressed in tandem with operational carbon. Importantly, they were among the first to highlight that the early planning and design phases of a project offer most potential for embodied or capital carbon reduction.

Of major significance, as shown in Figure 3, they highlighted: "Build nothing: challenge the root cause of the need", coupled with "explore alternative approaches to achieve the desired outcome" (italics added), could achieve a $100 \%$ reduction. In addition, "Build less: maximise the use of existing assets, optimise asset operation and management to reduce the extent of new

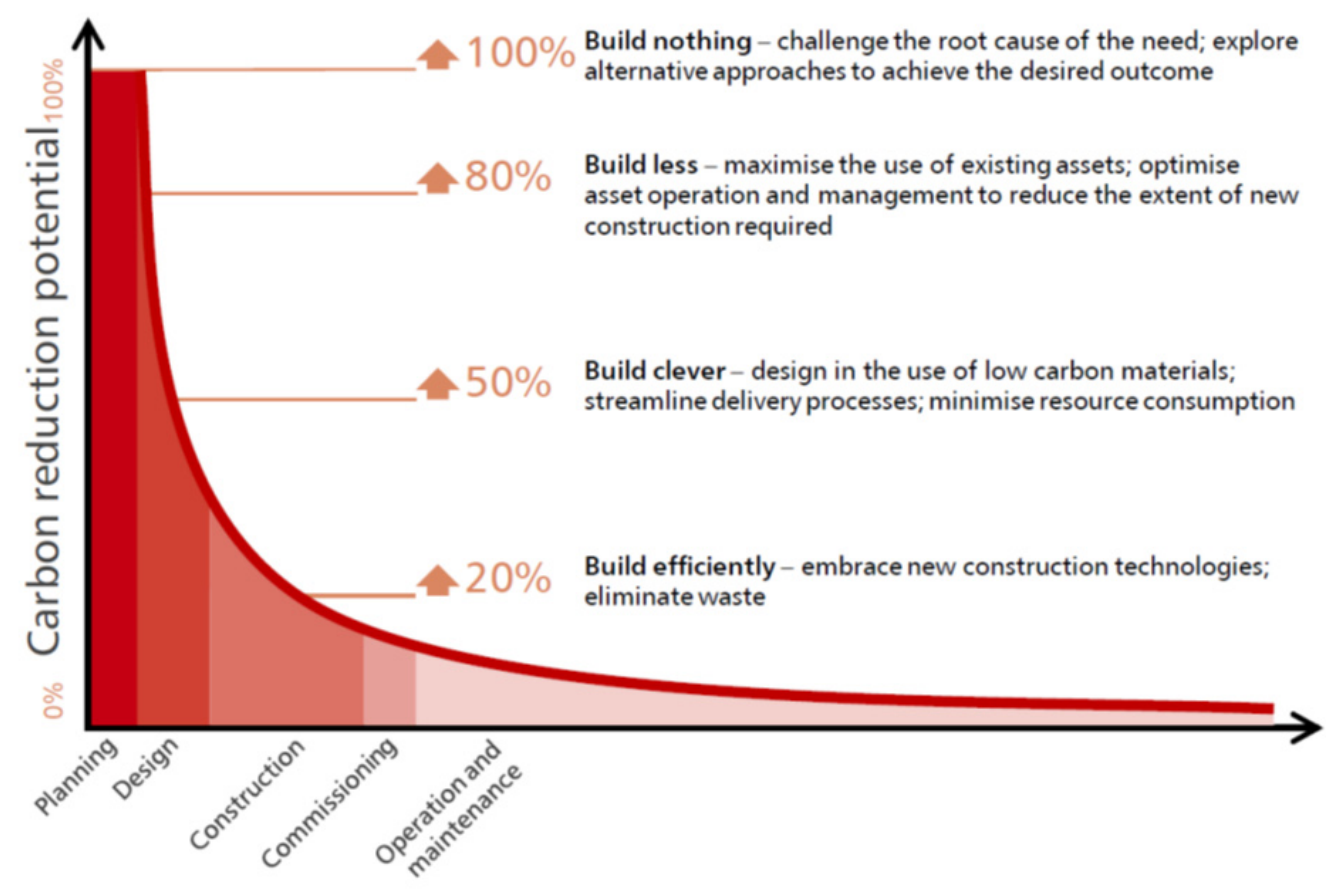

Figure 3. Tackle carbon early. Source: HM Treasury (2013) and Green Construction Board (2013), reproduced under the terms of the Open Government Licence (Crown Copyright 2013). 
construction required" ( $80 \%$ reduction), followed by "Build clever: design in the use of low carbon materials" (50\%) and "Build efficiently: embrace new construction technologies" (20\%). "The best way to reduce embodied carbon is through prevention". Moreover, as HM Treasury (2013, p. 11) explained, adopting the above concepts:

“...may require clients, consultants, contractors and suppliers to "rethink some of their business models, many of which are fundamentally based on creating assets...helping clients to avoid construction, with its attendant cost and emissions, opens up new business opportunities."

More recently, the forward-looking UK Green Building Council (UKGBC, 2019a, p. 25) incorporated this thinking in its 'framework definition' for net zero carbon buildings, followed by the WGBC (2019a). Meanwhile, the business model of the CRE sector remains based on asset creation, where supply precedes demand (Ness, 2019a).

\section{Commercial real estate: continuing to 'build big'}

Although the CRE sector has been identified as one of the biggest consumers of resources (University of Cambridge, 2014), it appears blind to the above developments and new thinking. The sector continues to 'build big', while claiming to be 'green' and supported by investment in green bonds.

Advocating much stronger efforts to reduce emissions, the Carbon Real Estate Risk Monitor (CRREM, 2019b) calculated that the sector is 14 years behind schedule, with its carbon budget available for 2050 consumed by 2036 . In rather an understatement,
CRREM (2019a, xii) admitted "The real estate industry has not been the most proactive in embracing the decarbonization agenda". Recognising that owners and investors have a crucial role to play in 'greening' the value chain, it recommended a holistic approach that is "closely related to the inevitable inclusion of embodied carbon considerations besides the well-established focus on operational carbon emissions".

With both embodied and operational carbon in mind, Gates (2019) announced that "buildings are bad for the climate". Seeking to heed this warning, Microsoft set a target of 15-30\% reduction in embodied carbon while redeveloping its Washington HQ. On the other hand, this may largely be negated because it is delivering 17 new buildings! (ULI, 2019, p. 11).

Despite high vacancy rates, supply of new office space often exceeds demand: rather than demand driving supply, the supply-driven property industry has claimed that "more needs to be done to ensure demand meets supply" (see Ness, 2019a). Cranes on the horizon have been used as an index of prosperity, with the supply of new office stock - and the bigger the project the better - "providing the impetus for significant job creation and economic development." Moreover, such massive projects have been able to tout their supposed 'green' credentials.

For example, Isaacson (2019) recently reported that Facebook would occupy 1.5 million-square-feet (140,000 square metres) within the 18 million-square-foot (1.67 square metres) megaproject Hudson Yards (Figure 4). What is more, the bulk of

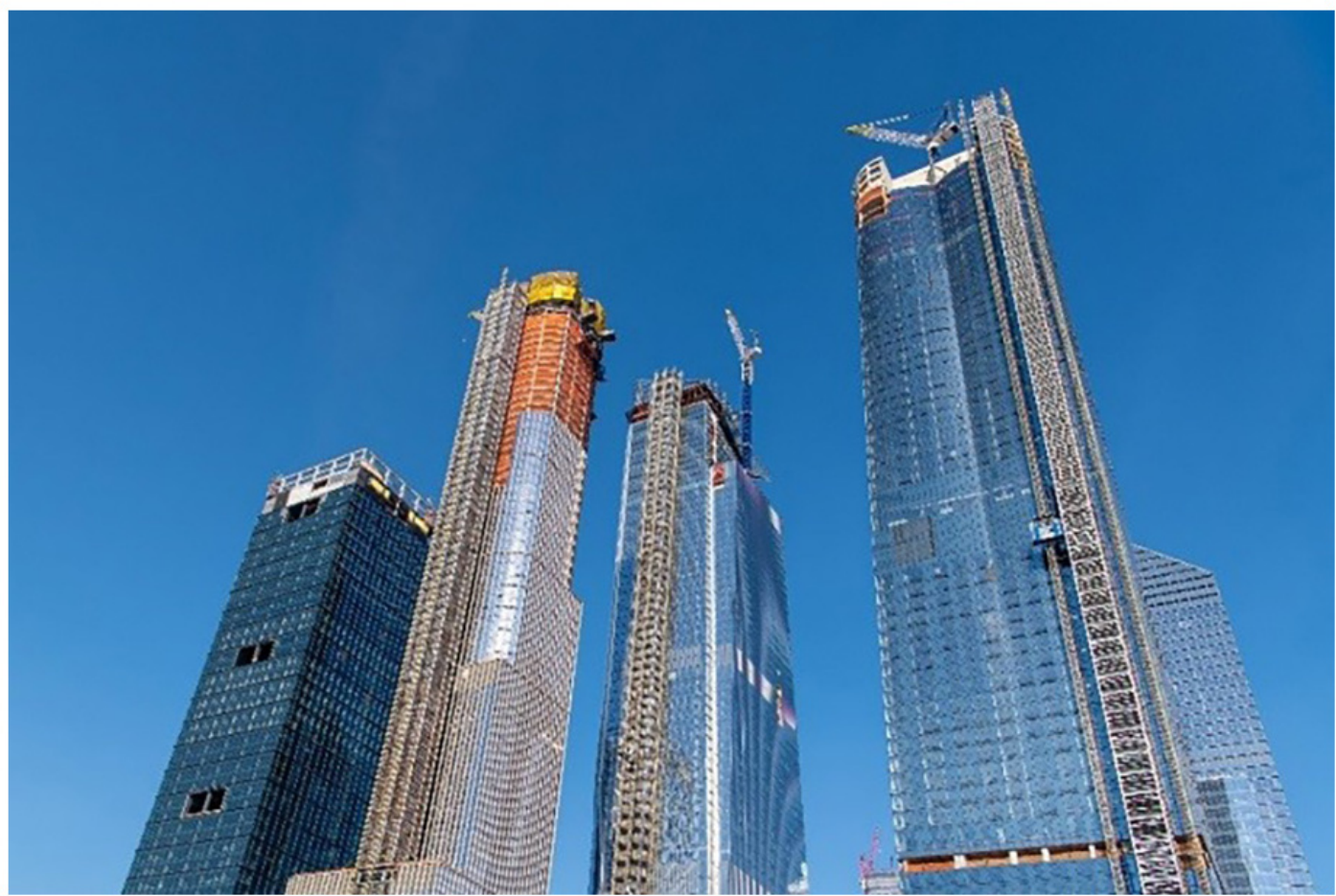

Figure 4. Construction of office and residential towers at Hudson Yards. Source: ( Jim Ekstrand / Alamy Stock Photo. 
Facebook's leased space would be within a 78-story tower that was expected to gain LEED 'Gold' certification. What is more, according to Hamman (2019) the 3.8 million square foot (353,000 square metres), 110-story Willis Tower, Chicago, gained highest LEED 'Platinum certification' due to energy and water system upgrades, while adding an additional 425,000 square feet $(39,500$ square metres). Surely something is amiss?

Sydney's Barangaroo is yet another example. Comprising 535,000 square metres of floor space for offices, apartments, retail and a casino, no effort has been spared in attaining a Six Star Green Communities Rating and the stated goal of achieving "the first precinct globally to be carbon neutral." Even the GBCA is proudly housed within International Towers, which were built using low-carbon concrete and steel, achieving a $20 \%$ reduction in embodied carbon compared with standard practice. This is coupled with use of recycled water, shading technologies, renewable energy strategies, and more. As the NSW Government (2019) announced, Barangaroo is among 19 projects around the world participating in the C40 Cities' Climate Positive Development Program (C40 Cities, 2016). But such features, while welcome, are not enough (Ness, 2019b).

In accordance with 'Advancing Net Zero', the WGBC (2018) net zero carbon buildings commitment, major CRE companies have pledged to take urgent action to ensure their own portfolios of buildings arrive at net zero carbon by 2030 or sooner. In addition, embodied carbon is now on the agenda. The Urban Land Institute's newly released report, 'Embodied carbon in materials for real estate' (ULI, 2019), explains how reducing embodied carbon in construction can save developers money and mitigate impacts of climate change, while the UKGBC (2019b) produced a guide to reporting of Scope 3 emissions (including embodied) in commercial real estate.

Meanwhile, the Chief Executive Officer of the GBCA (Madew, 2017) proudly proclaimed:

"Australia's real estate market was named as the world's most sustainable for the seventh year in a row... We now have more than 1,715 Green Star rated projects around the country, and $37 \%$ of our office space is Green-Star certified...42,000 live in Green Star apartments. A massive 1.3 million people visit a Green Star shopping centre each day."

The GBCA, it seems, is focussed on growth in 'green' certified projects - while being blind to the possibility of reducing carbon by constraining the number and size of projects.

Thus, the CRE sector - which seems wedded to growth in new construction - must make stronger and more fundamental changes to respond to the climate crisis (CRREM, 2019a). This will require adopting a wider view of 'green' that encompasses resource consumption and impact upon the existing stock, while striving for less new construction.

\section{Stronger intervention needed}

In tackling resource consumption, it is time to move beyond mere efficiency and seek to satisfy societal needs with minimal or even nil material input; to minimise the flow of matter through the economy by decreasing both the volume of flow and the speed of flow (Stahel, 2008).

In a similar vein, Naess (2006) called for much stronger interventions beyond improved efficiency, described as a "weak approach to sustainable consumption policy making". Bengtsson et al. (2018) added that:

"A weak approach focuses, for example, on incrementally improving the fuel economy of automobiles, while a strong approach would explore a much wider range of options for cutting emissions from transportation - including other forms of transport as well as how mobility might be transformed."

Demonstrating a similar line of thought, Shove (2017) argued that: "Programmes of energy efficiency are politically uncontroversial precisely because they take current interpretations of 'service' for granted....and carry normative assumptions about 'need' forward". She questioned current approaches that seek "equivalence" of service:

"...there might be ways of crafting buildings and equipment that do not meet present needs, and that do not deliver equivalent levels of service, but that do enable and sustain much lower-carbon ways of life...The problem with efficiency is that it maintains the status quo, and in so doing helps perpetuate unsustainable ways of life."

The challenge, then, is to debate and extend meanings of service, service levels, and the objectives of 'efficiency'. This requires taking a wider 'system' perspective, which "allows consideration of alternative ways of governing the provision of energy and materials" and "brings issues of fairness and social justice to the fore" (Bengtsson et al., 2018, citing Lebel \& Lorek, 2008).

\section{The service or performance economy}

The notion of a service or knowledge-based economy is not new. It gained currency in the early 2000s (Rifkin, 2000) and forms the basis of Stahel's "performance economy", where the focus is on delivering services and performance outcomes with less material input (Stahel, 2010). This resembles the notion of 'dematerialisation' that assumed prominence in the early 2000s (Mont, 2001), and the idea of 'product-service systems' where, as Ayers (1999) explained, products acted as 'messengers' to deliver services. Following such thinking, 'consumers' become 'customers' of product-service offerings by service providers.

Consistent with this line of thought, the ARUP-UniSA Global Research Challenge 2017 - in seeking to apply CE principles to the built environment - developed a prototype "cloud platform' for the ongoing exchange and reuse of modular building components, and their provision as a 'service' (ARUP, 2018). By retaining ownership of components and products, the supplier (service provider) could manage and remotely monitor their condition and performance over their extended life, while taking them back for repair or remanufacture where necessary. However, in the subsequent acceptance of a CE, where more value is gained from materials and products by such reuse and 
stewardship, the essential focus on services has been largely lost. Instead, our attention is diverted to the materials and products themselves, often with waste reduction in mind, not the purpose or performance requirements of the products.

The world's increasing embrace of the CE, including the notion of a circular built environment, again illustrates that most attention is at the level of material resources, in this case their reuse and recycling. The fundamental purpose or service outcomes, which the materials, buildings or infrastructure are intended to support, is often overlooked. This requires us to elevate our sights to services, on the ends rather than just the means.

These may include social and community services such as health, education, housing, transport, employment opportunities and the like, utility services such as water, energy and waste management, or environmental services such as biodiversity, clean air and the like. These requirements for quality of life and well-being may be grouped under socio-ecological services - a topic to which we shall return later.

\section{Shifting our sights to services}

Carmona et al. (2017, p. 9) posed the important question: "How can a $21^{\text {st }}$ century knowledge-based economy operate so that services, and not products, are at the forefront of development?" They made the highly insightful and critical observation $(2017,2)$ that:

“...comparing alternative pathways for providing the same service with lower resource needs will create space for societal transformation triggered by a more holistic view of sustainable development".

This, then, forms the embarkation point for our journey in the remainder of this paper.

Switching our focus to service outcomes may open-up whole new ways of thinking. For example, the profit centre for utilities such as energy, water or waste management companies could be shifted towards the function provided (Mont, 2001); the profit centre is not in the amount of energy sold, but in the provision of a constant input of power and in reduction of the energy flow (Ness, 2008).

Similarly, third party energy services companies supply energy efficiency services, making their profits via reductions in energy consumption for customers. Under a similar performance or result-based business model, the profits of infrastructure providers or facility managers could derive from improving the operational service outcomes of the infrastructure or buildings. The most environmentally sound and inexpensive solution is the one that doesn't need to be built because the provider has met customer needs with less cost and less carbon.

Carmona et al. (2017) used a 'Russian doll' analogy to illustrate the progression from energy and material efficiency to "material service optimisation", from both a product and stock perspective. This ranged from "zero eyes open" (turning a blind eye to materials), to "one eye open" (glancing at materials but fixed on energy), to "both eyes open" (looking but not really seeing), to "eyes wide open" (looking forward to the sustainable development horizon). This "eyes wide open" strategy, they claimed, adds value by considering consumption and the wider effect that materials services have on societal and environmental wellbeing.

This strategy "requires a strategic re-think of how materials are thought of, valued and used. It breaks the paradigm of seeing materials as products and emphasises the services behind them", based upon the notion of "material services optimisation" (Carmona et al., 2017, p. 9). This idea should extend far beyond manufactured products to the wider built environment, which - as we have seen - is the largest consumer of material resources in the world.

\section{'Growth does not mean size'}

A drastic rethink and reset are required within the CRE, construction and business sectors, before it is too late. This begins with a change in mindset, where "growth does not mean size." As Burns (2019) highlighted, this comment was made by the head of a major global water and waste organisation when announcing the company's 2030 vision:

"He was referring to physical size for he went on to speak of reducing capital (physical structures) and increasing IT, of focusing not on 'growth' as such, but on selecting just those areas in which they could add most value. In other words, to grow performance and profit. And yes, profit is a 'good thing', if it is a reflection of good performance."

Governments tend to foster more and bigger buildings, viewing this as an indicator of prosperity, job creation and success. It will be a challenge for them, the construction and CRE sectors, to value what is "smaller and smarter". However, while commercial office space expands exponentially, the digital revolution and other trends are likely to reduce demand, as in the case of retail, education, health and other facilities. Are office towers, now under construction, destined to become extinct dinosaurs or 'stranded assets' looming over the skylines of our future cities?

CRE will need to respond to changing business demands and new patterns of work, where employees may be able to operate from remote locations, while collaborating and meeting online. At the recent 'SPACE' 'progressive property' conference, Dugarin (2019) sought to "repair the disconnect between humans and real estate", noting that "for too long the property industry operated as a product industry". The same event canvassed topics such as responsible and sustainable real estate, future-proofing the value of assets, co-working, flexibility, and digital transformation and infrastructure. Thus, functions may be delivered in alternative and less resource intensive ways, involving more intense utilization of existing space, adapting and reusing existing premises, building less, and even not building at all.

According to CRREM (2019a), the "real estate bias in favour of new build solutions" needs to be countered by evidence-based justification and business cases to support more serious consideration of "green retrofitting" solutions. In a positive initiative, CRREM has undertaken to prepare such guidance. 


\section{Strategic asset management to the rescue}

Kohler (2018, p. 589) has lamented that "architecture is still reduced to the notion of new build design", while the green and sustainable building movement has shown little interest in existing buildings and building stocks. Emphasizing a "resourcebased (capital) definition of the built environment", he sought "to extend decision-making from the design of new buildings to a number of situations...during the lifetime of a real building".

To support this important direction, management and stewardship of the existing building stock must assume increased importance. The principles of strategic asset management, as set down in ISO 55000 (ISO, 2014), will also need to be brought to the fore - beginning with an understanding of service requirements and organisational objectives:

"Asset management does not focus on the asset itself, but on the value that the asset can provide to the organisation. The value...will be determined by the organization and its stakeholders, in accordance with the organizational objectives."

Strategic asset management can benefit an organisation in delivering community, social and utility services in an effective and efficient manner, while "demonstrating social responsibility", including its ability to "reduce emissions, conserving resources, and adapt to climate change". On the other hand, when maximum profitability takes precedence, there is a risk of 'rebound effects' when increasing economic surplus may be channeled into investments and activities that are not environmentally benign.

In the new regime, extending the life-span of buildings and their parts, coupled with the long-term management of the existing stock, assumes increased importance. At present, new buildings are designed with present functions and services in mind. With the passing of time, these may become increasingly obsolete, lose their value, and sink irreversibly to the bottom of the stock. To avert this fate, conserve the value of the building stock, and "ensure the optimal use of resources in a longer-term perspective" (Kohler, 2018, p. 580), a life-cycle view is required - whereby buildings and their surrounds are designed for adaptability and resilience. In this regard, the concept of 'shearing layers of change', involving the ' 6 Ss' of Systems, Site, Structure, Services, Space and Stuff (see Brand, 1995) should be recognised and applied, as should the principles of 'Open Building' exemplified by the 'Next21' Building, Osaka, 1994 (Habraken, 2003). These ideas are not new - but how many new buildings are designed for adaptability and disassembly? Even in the present 'climate emergency', buildings are designed as though resources are unlimited.

This points to the need for the 'build big' agenda to be challenged and reframed, supported by a set of policies and mechanisms.

\section{A way forward: policies and mechanisms}

\section{Reframing the agenda}

The current agenda that 'bigger is better, and even greener' needs to be reframed to 'smaller and smarter is better, and critical to attainment of net zero carbon by 2050'. By switching our focus to services and performance outcomes, we can examine ways to meet genuine needs with less material and other resources, less carbon, less waste and less cost.

The reframed agenda should also highlight the value of managing and conserving human, material, natural capital and stocks, where true wealth resides (Stahel, 2010). Contrary to popular belief, the more labour-intensive maintenance, adaptation and refurbishment of existing building stocks is a better employment generator than new construction (Kincaid, 2002), while asset and facilities management can create longer-term jobs in the services sector.

This new agenda could be set within the wider framework of 'ecological economics', where economic growth is seen as a means of achieving the ends of socio-ecological transformation - a vision of prosperity based on much less material abundance and consumption, with alternative pathways to well-being (Kallis et al., 2012). Such a vision is entirely consistent with 'shifting our focus to services', as discussed earlier. It would represent a dramatic change from prevailing approaches, where social and ecological concerns are often marginalized as sub-disciplines of economics (Morgan, 2017; Santarius et al., 2016).

Van Griethuysen (2012, p. 265) put forward inter-related ways whereby "capitalist property expansion could be subordinated to eco-social considerations", including limiting the scope of the property domain, regulating capitalization practices, orienting investments, and allocating monetary returns and distributing created wealth. In general, the following set of policies and mechanisms accord with his suggestions.

\section{Allocations and targets}

According to the Graz Declaration (SBE, 2019), governments have a role to establish policies and frameworks for enabling the transition towards net zero-carbon built environments. Specific targets and budgets are needed for the construction and property sectors: "...these need to be scalable (both top-down and bottom-up for construction products, buildings, cities, building stocks) and have clearly defined timeframes...”.

In this regard, the UKGBC (2019c) has already opened a consultation on "energy use intensity" (EUI) targets for commercial offices based on the "Paris proof" concept developed by the Dutch Green Building Council. This involves a top-down calculation based upon the estimated capacity of renewable energy generation in 2050, its allocation based on current energy consumption, leading to allocation of "simple and clear" EUI targets for individual buildings. The possibility of similar allocations and targets for embodied carbon, even for building size, is beyond the scope of this paper and will require further consideration (Giesekam et al., 2018).

\section{Development controls}

In many jurisdictions, planning systems encourage 'bigger and more' in the name of supposed economic progress and more jobs. Developers in the City of Adelaide, for example, were excited at the removal of height and other restraints, enabling them "to reach for the sky...unless you're galactically stupid, doing something in the city complies". However, such a building bonanza in a saturated 
market often has adverse consequences. The addition of new real estate will displace older existing stock, due to the gravitation of tenants to new accommodation, known as the "flight to quality". This precipitates the increased vacancy and obsolescence of lower grade stock existing stock, which may be 'withdrawn' from the market and become waste.

Although planning systems shy away from interference in the market, a case can be made for restraining new construction on the grounds of 'community externalities' caused by vacant buildings, associated loss of amenity and rate income, and inability to meet city targets for carbon neutrality (Ness, 2019a). This can be accompanied by rate and tax incentives to foster adaptation and refurbishment.

\section{Carbon accounting}

At present, under the Greenhouse Gas Protocol (WRI et al., 2015), cities can claim they are 'carbon neutral' based upon reduced operational carbon within their territorial boundaries. For example, the City of Adelaide announced that it had successfully achieved "decoupling of economic growth and carbon emissions"; despite the addition of 243,000 square metres of office stock, emissions had been reduced by $23 \%$ due to energy efficiency and renewable energy (Ness, 2019a, p. 80).

Such claims will become more difficult to justify when Scope 3 emissions, including embodied carbon associated with imported building products and other goods, are sheeted home to consuming cities. As C40 Cities (2018) noted, accounting for consumption-based emissions could increase city emissions by up to $60 \%$.

\section{Finance and investment}

The combination of proactive government policies and technological advances is encouraging institutional investors to consider carbon risk reduction as a core component of investment strategy. "Measuring a company's carbon footprint is a necessary first step towards the creation of a broader climate change strategy" (CRREM, 2019a, xvii). A decision to build less, or not build at all, will reduce the carbon footprint of an organisation, not to mention cost-savings.

The likely advent of carbon pricing will increase the viability of adapting existing buildings, as the carbon is already spent and is a 'sunk cost'. New build, on the other hand, will entail the use of new resources, new carbon, and the associated cost.

The ULI (2019) has claimed that "reducing embodied carbon in construction can save developers money and mitigate impacts of climate change"; transitioning to a low carbon economy is touted as "a multi-billion-dollar investment opportunity" (NABERS et al., 2019), while the GBCA (2019) announced US\$250 billion of 'green bonds' was expected to be issued in 2019. However, green building rating tools, which play a major role in attracting such 'sustainable finance', currently attach most weight to reductions in operational carbon. These tools require urgent adjustment to address resource consumption and embodied carbon, with credits awarded for retrofit, reuse, and design for disassembly.
The reframed 'smaller and smarter' agenda, supported by a set of policies and mechanisms such as outlined above, may provide the impetus for a substantial transformation in global policies and approaches towards reducing GHG emissions associated with the built environment.

\section{Concluding remarks}

The construction sector is a laggard in reducing GHG emissions, with Stewart (2019) of the WRI claiming that fewer than $1 \%$ of buildings are zero carbon today. In "raising ambition to decarbonise the building sector everywhere", the WRI (2020) has focused largely (once again) on "high levels of energy efficiency." As explained earlier, this is not enough.

With the climate emergency demanding grander ambitions and stronger action, it is time for the sector to grasp fully the opportunities from tackling embodied or 'capital carbon'; not only at the level of low carbon materials, but also (more importantly) at the strategic planning level. As we have seen, the inception and planning phases of projects - including 'build nothing' and 'build less' have the most potential for carbon reduction (up to $80-100 \%$ ). Even before a building project emerges, the service demand should be questioned, and alternative options carefully considered. However, such strategies may be at odds with capitalist property expansion and, to be fully effective, are likely to require changes to economic systems that currently depend upon increased material growth and accumulation.

This requires a greater understanding and application of strategic asset management principles which, until now, have been largely overlooked in pursuit of net zero carbon and conserving scarce resources. This includes a portfolio wide view of an organisation's assets, close alignment of assets with service needs, and increased adaptation of existing assets. The likely advent of carbon pricing will surely increase viability, as less carbon and cost will be incurred for new construction. Other policies, regulatory controls and mechanisms, which limit capitalist property expansion and foster more modest, less-material intensive solutions, should also form part of a reframed agenda.

Most of all, whilst resource efficiency and reuse of materials and products may achieve some gains, it is essential that growth in the area and mass of the built environment is restrained, especially in slow-growing industrialized countries that may already be well-endowed with facilities and infrastructure: “...the key issue at stake is unbalanced resource consumption on a global level, an issue of global ethics" (Stahel, 2008, p. 508). While it is also necessary to replace ageing and polluting capital stock in developed economies, the NCE (2018, p. 20) acknowledged that the greatest increases in building stock and infrastructure "will primarily happen in emerging markets and developing countries". In his study of the carbon footprint of material production, Hertwich (2019) observed: "Policies addressing the rapidly growing capital stocks in emerging economies...offer the best prospect for emission reductions..."

In such contexts, given scarcity of funds for constructed assets and other spending priorities, efforts should firstly be focused 
on extracting increased performance from existing infrastructures (Tafazzoli, 2017). When new infrastructures are required, these should be planned as integrated, adaptable and localised systems, so that multiple service outcomes may be provided with less capital expenditure and less material resources (UN, 2011).

Focusing upon the CRE sector, this paper has sought to throw this present 'blind spot' into stronger focus, with - as expressed by Carmona et al. (2017) - our "eyes wide open." Due to the significance of the construction sector in reducing emissions and resource consumption, coupled with its role in achievement of the UN Sustainable Development Goals (including SDG 12: 'Responsible Consumption and Production' and SDG 11: 'Sustainable Cities'), this is a matter of global importance. Prevailing approaches of international organisations, including the widespread belief that increased growth (especially material growth) can support climate action, have also been challenged. The notion of having service demands uppermost in our minds, while exploring less material intensive ways to meet genuine needs, may be extended beyond CRE to the wider built environment, urban planning, and other sectors such as food, industry, transport and the like.

Finally, this opinion paper has sought to set a fresh research direction, with the potential - as shown in Box 1 - to make deep cuts to carbon emissions. More evidence, theory, a 'manifesto' and a model to support this direction can be found in Ness (2019a) and Ness \& Xing (2017).

\section{Data availability}

No data is associated with this article.

\section{Acknowledgements}

The author is grateful to his close colleague Dr Ke Xing, with whom he has developed service-system innovation approaches, and to Dr Penny Burns for her knowledge and insight of strategic asset management over many years.
Allwood J: Squaring the circular economy: the role of recycling within a hierarchy of material management strategies. Chapter $30 \mathrm{in}$ : Worrell $\mathrm{E}$, and $\mathrm{M}$ Reuter (eds), Handbook of recycling: state of the art for practitioners, analysts, and scientists. Elsevier, Amsterdam, 2014; 445-477. Publisher Full Text

Allwood JM, Gutowski TG, Serrenho AC, et al:: Industry 1.61803: the transition to an industry with reduced material demand fit for a low carbon future. Philos Trans A Math Phys Eng Sci. 2017; 375(2095): pii: 20160361.

PubMed Abstract | Publisher Full Text | Free Full Text

Architecture 2030: Zero code: the future has arrived. 2018.

Reference Source

Architecture 2030: New buildings: operational emissions. (Accessed 7 Jan 2020), 2020a.

Reference Source

Architecture 2030: Carbon smart materials palette. (Accessed 7 Jan 2020), 2020 .

Reference Source

ARUP: Circular Cities: Reduce. Reuse. Rebuild. ARUP Res Rev. 2018; (1). Reference Source

Ayers R: Products as service carriers: should we kill the messenger - or send it back? Zero Emissions Forum, Tokyo: UN University, 1999.

Reference Source

Bengtsson M, Alfredsson E, Cohen M, et al.: Transforming systems of consumption and production for achieving the sustainable development goals: moving beyond efficiency. Sustain Sci. 2018; 13(6): 1533-1547. PubMed Abstract | Publisher Full Text | Free Full Text

Bocken N, Short S: Transforming business models: towards a sufficiencybased circular economy. In: Brandão M, Lazarevic D, Finnveden G. eds., Handbook of the Circular Economy. Edward Elgar Publishing. Cheltenham, UK 2020.

Reference Source

Brand S: How buildings learn: what happens after they're built? Penguin Books, 1995

Reference Source

Burns P: Growing smaller but smarter. Talking Infrastructure. 2019.

Reference Source

C40 Cities: Climate positive development program. 2016.

Reference Source

C40 Cities: Consumption-based GHG emissions of C40 cities. C40 Cities

Climate Leadership Group, 2018

Reference Source

C40 Cities: Buildings and infrastructure consumption emissions: in focus. C40 Cities, ARUP and University of Leeds. 2019.

Reference Source
Carbon Leadership Forum: Take action to reduce the carbon emissions of building materials. (accessed 7 Jan 2020), 2020.

Reference Source

Carmona L, Whiting K, Carrasco A, et al:: Material Services with Both Eyes Wide Open. Sustainability. 2017; 9(9): 1508.

Publisher Full Text

Chapa J: Australia steps up to the challenge to decarbonise. Green Build Counc Aust. 2019.

Reference Source

CRREM: Carbon risk integration in corporate strategies within the real estate sector. Carb Risk Real Estate Monit. 2019a.

Reference Source

CRREM: Stranding risk \& carbon: science-based decarbonising of the EU commercial real estate sector. Carb Risk Real Estate Monit. 2019b.

Reference Source

De Decker K: How circular is the circular economy? Low-Tech Mag. 2018. Reference Source

Dugarin T: Repairing the disconnect between humans and real estate. SPACE Progressive Property Conference, London, 2019

Reference Source

EMF: Completing the picture: how the circular economy tackles climate change. Ellen MacArthur Foundation, V3, 2019.

Reference Source

Floater G, Rode P, Robert A, et al.: Cities and the New Climate Economy: the transformative role of global urban growth. New Climate Economy Cities Paper 01. LSE Cities. London Sch Econ and Polit Sci. 2014.

Reference Source

Gates B: Buildings are bad for the climate: here's what we can do about it. GatesNotes. 2019.

Reference Source

GBCA: A carbon positive roadmap for the built environment Stage 1: Commercial, institutional and government buildings and fitouts (for discussion). Green Build Counc Aust, 2018.

Reference Source

GBCA: Climate and capital come together. Green Build Counc Aust, 2019. Reference Source

GBCA, PCA: Every building counts: a practical plan for emissions reduction. Green Build Counc Aust and Prop Counc Aust, 2019.

Reference Source

Giampietro M: On the circular bioeconomy and decoupling: implications for sustainable growth. Ecol Econ. 2019; 162: 143-156.

Publisher Full Text

Giesekam J, Tingley DD, Cotton I: Aligning carbon targets for construction with (inter)national climate change mitigation commitments. Energ Buildings. 2018; 
165: $106-117$.

Publisher Full Text

GlobalABC, IEA, UNE: Global status report for buildings and construction: towards a zero emissions, efficient and resilient buildings and construction sector. Glob Alliance Build and Construction, Internatl Energy Agency and UN Environ Program, 2019

Reference Source

Green Construction Board: Low Carbon Routemap for the UK Built Environment. 2013.

Reference Source

Habraken $\mathrm{NJ}$ : Open building as a condition for industrial construction. ISARC 2003: the future site: proceedings of the $20^{\text {th }}$ Internatl symp auto robot construction, Maas, G.J. and Gassel, F.J.M. (eds), 21-24 Sept, Eindhoven. 2003 Publisher Full Tex

Hamman J: Willis tower achieves LEED platinum. Commercial Property Executive. 2019

Reference Source

Harvey F, Rankin J: Paris climate deal: world not on track to meet goal amid continuous emissions. The Guardian. 2019.

Publisher Full Text

Hertwich $E$ : The carbon footprint of material production rises to $23 \%$ of global greenhouse gas emissions. SocArXiv Papers. 2019.

Reference Source

HM Treasury: Infrastructure carbon review. London, 2013.

Reference Source

Hughes E: How LEED 4.1 addresses embodied carbon. Facilitiesnet. 2019. Reference Source

IRP: The Weight of Cities: Resource Requirements of Future Urbanization. Report by Internatl Resour Panel. UN Environ Progr, Nairobi, Kenya. 2018 Reference Source

Isaacson G: Facebook leases 1.5 MSF at New York City's Hudson Yards. Commercial Property Executive, 2019.

Reference Source

ISO: ISO 55000: 2014, Asset management: overview, principles and

erminology. Internatl Standards Association. 2014.

Reference Source

Jiang $\mathrm{M}$, Behrens $\mathrm{P}$, Wang $\mathrm{T}$, et al.: Provincial and sector-level materia footprints in China. Proc Natl Acad Sci U S A. 2019; 116(52): pii: 201903028. PubMed Abstract | Publisher Full Text | Free Full Text

Kallis G, Kerschner C, Martinez-Alier J: The economics of degrowth. Ecol Econ. 2012; 84: 172-180.

Publisher Full Text

Kincaid D: Adapting buildings for changing uses: guidelines for change of use refurbishment. London, Spon Press. 2002.

Publisher Full Text

Kohler N: From the design of green buildings to resilience management of

building stocks. Build Res Inform. 2018; 46(5): 578-593.

Publisher Full Text

Lebel L, Lorek S: Enabling sustainable production-consumption systems. An Rev Environ Res. 2008; 33: 241-275.

Publisher Full Text

Madew R: Progress and practical action. Green Build Counc Aust, 2017. Reference Source

Millar N, McLaughlin E, Börger T: The circular economy: swings and

roundabouts? Ecol Econ. 2019; 158: 11-19.

Publisher Full Text

Moffatt S, Russell P: Assessing the adaptability of buildings. IEA Annex 31:

Energy-related environ impact build, 2001.

Reference Source

Mont O: Introducing and developing a product-service system (PSS) concept in Sweden. Intern Inst Indust Environ Econ (IIIEE), Lund University. 2001.

Reference Source

Morgan J: Piketty and the growth dilemma revisited in the context of ecological economics. Ecol Econ. 2017; 136: 169-177.

Publisher Full Tex

NABERS, GBCA, GRESB, et al:: Maximising your investment: Using rating tools to attract sustainable finance for real estate. National Australia Building Energy Rating System. 2019

Reference Source

Naess P: Unsustainable growth, unsustainable capitalism. J Crit Realism. 2006; 5(2): 197-227.

Publisher Full Tex

Naess P: Urban planning: residential location and compensatory behaviou in three Scandinavian cities. In: Rethinking climate and energy policies. New perspectives on the rebound phenomenon, Santarius T, Walnum HJ, Aall C (eds): Springer. 2016; 181-207.

Publisher Full Text

Ness D: Sustainable urban infrastructure in China: Towards a Factor 10 improvement in resource productivity through integrated infrastructure systems. Internatl J Sus Dev World Ecol. 2008; 15(4): 288-301.

Reference Source

Ness D: The impact of overbuilding on people and the planet. Cambridge
Scholars Publishing, 2019a.

Reference Source

Ness D: Architecture's love affair with extravagant new build must end. Arch J. 2019b.

Reference Source

Ness D, Xing K: Towards a resource-efficient built environment: a literature review and conceptual model. J Ind Ecol. 2017; 21(3): 572-592.

Publisher Full Text

NCE: Better growth, better climate. The 2014 New Carbon Economy Report, Glob Comm Econ and Climate. 2014.

Reference Source

NCE: The sustainable infrastructure imperative: financing for better growth and development. The 2016 New Urban Economy Report, Glob Comm Econ and Climate. 2016.

Reference Source

NCE: Unlocking the inclusive growth story of the $21^{\text {st }}$ century: accelerating climate action in urgent times. The 2018 New Carbon Economy Report, Global Comm Econ and Climate. 2018.

Reference Source

NSW Government: Barangaroo and the C40. New South Wales Gov (accessed 10 Oct 2019). 2019

Reference Source

Rees W: The ecological crisis and self-delusion: implications for the building sector. Build Res Info. 2009; 37(3): 300-311.

Publisher Full Text

Rifkin J: The age of access: how the shift from ownership to access is

transforming capitalism. Penguin Books, London. 2000.

Reference Source

Santarius T, Walnum HJ, Aall C (eds): Rethinking climate and energy policies - new perspectives on the rebound phenomenon. Springer. 2016.

Publisher Full Text

SBE: Graz declaration for climate protection in the built environment. Graz, Austria. 2019

Reference Source

Schmidt-Bleek F: The Factor 10/MIPS-concept: bridging ecological, economic, and social dimensions with sustainability indicators. Factor 10 Instit, Carnoules. 2000.

Reference Source

Shove $\mathrm{E}$ : What is wrong with energy efficiency? Build Res Info. 2017; 46(7): 779-789. Publisher Full Text

Skene K: Circles, spirals, pyramids and cubes: why the circular economy cannot work. Sustain Sci. 2018; 13(2): 479-492.

Publisher Full Text

Stahel W: Global climate change in the wider context of sustainability. The Geneva papers. Geneva: Intern Assoc Study Insur Econ. 2008; 33(3): 507-529. Publisher Full Text

Stahel W: The performance economy. second edition. UK Palgrave MacMillan. 2010.

Publisher Full Text

Stewart E: Buildings are an ideal but overlooked climate solution. Eco-Bus. 2019. Reference Source

Tafazzoli M: Strategising sustainable infrastructure asset management in developing countries. ASCE Internatl Conf Sustain Architecture, NY 2017. Publisher Full Text

UKGBC: Net zero carbon buildings: a framework definition. 2019a.

Reference Source

UKGBC: Guide to Scope 3 reporting in commercial real estate. UK Green Build Coun. 2019b.

Reference Source

UKGBC: Consultation webinar: "Paris Proof" targets for commercial offices UK Green Build Coun. 2019c.

Reference Source

ULI: Embodied carbon in building materials for real estate. Urb Land Inst

(Greenprint). 2019

Reference Source

UN: Are we building competitive and liveable cities? Guidelines on developing eco-efficient and sustainable urban infrastructure in Asia and Latin-America. UNESCAP, Bangkok. 2011

Publisher Full Text

UN: The new urban agenda. Habitat III Quito. 2017.

Reference Source

UNE, IEA: Towards a zero-emission, efficient, and resilient buildings and construction sector. Glob Status Report, UN Environ and Intern Energy Ag. 2017. Reference Source

UNEP: Global material flows and resource productivity. An assessment study of the UNEP International Resource Panel. Paris, UN Environ Program. 2016.

Reference Source

University of Cambridge: Reducing material demand in construction: a prospectus for meeting the UK Government's 'Construction 2025' ambitions for capital carbon emissions. Dept Energy, 2014.

Reference Source 
Use Less Group: A use less guide to construction. (accessed 7 Jan 2020), 2020 Reference Source

Van Griethuysen P: Bona diagnosis, bona curatio: How property economics clarifies the degrowth debate. Ecol Econ. 2012; 84: 262-269.

Publisher Full Text

Victor D, Geels F, Sharpe S: Accelerating the low carbon transition: the case for stronger, more targeted and coordinated international action. Brookings Instit,

2019.

Reference Source

Von Weizsäcker E, Lovins A, Lovins LH: Factor 4, Doubling wealth - halving

resource use. Earthscan: London. 1997.

Reference Source

WGBC: The net zero carbon buildings commitment. World Green Build Counc, 2018. Reference Source

WGBC: Bringing embodied carbon upfront. World Green Build Counc, 2019a. Reference Source
WGBC: Big step-up in ambition needed to put buildings and construction on track to meet Paris Agreement goals, warns GlobalABC report. World Green Build Counc, 2019b.

Reference Source

WRI: Zero carbon buildings for all. World Res Inst: Ross Cent. (accessed 7 Jan 2020), 2020.

Reference Source

WRI, C40, ICLEI: Greenhouse Gas Protocol: Global protocol for communityscale greenhouse gas emission inventories-An accounting and reporting standard for cities. Washington DC: World Resources Instit, C40 Cities, and Local Govern for Sustain (ICLEI). 2015

Reference Source

Yan D: Current status and reduction on potential for materials use in buildings construction in China. IEA Experts' Dialogue on Materials Trends in Build

Construction. Paris. 2018.

Reference Source 


\section{Open Peer Review}

\section{Current Peer Review Status:}

\section{Version 2}

Reviewer Report 14 April 2020

https://doi.org/10.21956/emeraldopenres.14553.r26682

(C) 2020 Naess P. This is an open access peer review report distributed under the terms of the Creative Commons Attribution License, which permits unrestricted use, distribution, and reproduction in any medium, provided the original work is properly cited.

\section{Petter Naess}

Department of Urban and Regional Planning, Faculty of Landscape and Society, Norwegian University of Life Sciences, Ås, Norway

I think the article is very important and should now been accepted. Although I had hoped for somewhat more elaborate discussion in the revised text of the issues I raised in my previous review, I do not think this should block the article from now being accepted.

I would, however, challenge the author to reflect (in future publications) on the following questions:

1. Is it possible to obtain a full decoupling between capital accumulation and growth in consumption?

2. Given that large parts of the population, especially but not only in the global south, live under poor housing conditions, what would be the distributional implications of a 'build less' or 'build nothing' scenario if the basic housing needs of the poor are to be met?

I discovered a typo that should be corrected in the final version: Just above Figure 4, the author writes '1.67 square metres'. This should be changed to 1.67 million square metres.

Competing Interests: No competing interests were disclosed.

I confirm that I have read this submission and believe that I have an appropriate level of expertise to confirm that it is of an acceptable scientific standard.

Author Response 15 Apr 2020

David Ness, University of South Australia, Adelaide, Australia

Dear Prof Petter Naess

I am extremely grateful for your support even though I did not meet all your expectations. 
And assure you I will reflect deeply on the 2 insightful points you have highlighted, including for future publications.

Also thank you for reading again so carefully. Yes, I also detected that typo and will ensure it is corrected.

Finally, I wish to thank you (and other reviewers) for what has been a most useful learning experience for myself - and no doubt others too.

Sincerely

David

Dr David Ness

Competing Interests: No competing interests were disclosed.

Reviewer Report 20 March 2020

https://doi.org/10.21956/emeraldopenres.14553.r26681

(c) $\mathbf{2 0 2 0}$ Liu G. This is an open access peer review report distributed under the terms of the Creative Commons Attribution License, which permits unrestricted use, distribution, and reproduction in any medium, provided the original work is properly cited.

\section{Gang Liu}

School of Energy Science and Engineering, Central South University, Changsha, Peoples Republic Of China

This article is improved a bit according to some advice given.

Competing Interests: No competing interests were disclosed.

Reviewer Expertise: 1. Energy economy;2. Geothermal energy;3. Engineering thermophysics and energy utilization;4. New energy technology.

I confirm that I have read this submission and believe that I have an appropriate level of expertise to confirm that it is of an acceptable scientific standard.

\section{Version 1}

Reviewer Report 20 February 2020

https://doi.org/10.21956/emeraldopenres.14490.r26603 
(c) 2020 Pomponi $\mathbf{F}$ et al. This is an open access peer review report distributed under the terms of the Creative Commons Attribution License, which permits unrestricted use, distribution, and reproduction in any medium, provided the original work is properly cited.

\section{Francesco Pomponi}

Resource Efficient Built Environment Lab (REBEL), Edinburgh Napier University, Edinburgh, United Kingdom

\section{Bernardino D'Amico}

Resource Efficient Built Environment Lab (REBEL), Edinburgh Napier University, Edinburgh, United Kingdom

\section{Jay Arehart}

1 University of Colorado, Boulder, CO, United States

2 Resource Efficient Built Environment Lab (REBEL), Edinburgh Napier University, Edinburgh, United Kingdom

This opinion paper brings forward a shared (yet no strongly voiced) view among sustainability experts with regard the built environment and climate change. Specifically, the paper argues that technological advancements to increase material and energy efficiency (including the circular economy paradigm) will not suffice alone to help meeting GHG emission targets unless we also slow down the current pace at which new floor area is being constructed worldwide.

More generally, the paper is a critique toward the current model of economic growth in which new construction is considered (and valued) a synonymous of "prosperity, job creation and success". The Author therefore points out to the need for a focus shift (from products to services) in the way built environment is currently valued in order to explicitly account (in economic terms) for the environmental price of economic activities such as buildings/infrastructure construction.

The paper is well written and the opinion conveyed in it is well rooted and supported by the existing literature. One aspect that could be improved perhaps is in the second part of the paper, where the Author recalls existing thinking on the idea of a service or performance economy as the "way forward" to tackle resource consumption while meeting societal needs.

Relevant contributors in the field are cited (e.g. Ayers) however a more explicit acknowledgment to the field of Ecological Economics is missing.

Given the importance and relevance of this field of study in understanding the limitation of our current economic model for a sustainable growth, we would like to suggest the Author to consider framing his "way forward" by looking at the wider academic research context of Ecological Economics. A small paragraph would do.

Additionally, while this paper succinctly describes how strategic asset management can address the blind spot in reducing the carbon emissions of the built environment, the focus of the article is paid to addressing the mature building stocks of the global north. The Author notes in the Introduction that the global south will be responsible for much of the growth, yet there is no other mention of how less-mature building stocks might evolve to achieve global sustainability goals. It is suggested that a discussion and examples of strategic asset management in the context of the 
global south be included, as to strengthen the Author's arguments.

Overall, this submission fits well the 'opinion piece' type, seeking to break new ground and promote future deeper exploration. The use of persuasive quotes and arguments from different authors in diverse disciplines highlights well the multi- and inter-disciplinarity of the challenge.

Is the topic of the opinion article discussed accurately in the context of the current literature?

Yes

Are all factual statements correct and adequately supported by citations? Yes

Are arguments sufficiently supported by evidence from the published literature? Yes

Are the conclusions drawn balanced and justified on the basis of the presented arguments? Yes

Is the argument information presented in such a way that it can be understood by a nonacademic audience?

Yes

Does the piece present solutions to actual real world challenges?

Yes

Is real-world evidence provided to support any conclusions made?

Yes

Could any solutions being offered be effectively implemented in practice?

Yes

Competing Interests: No competing interests were disclosed.

Reviewer Expertise: Embodied carbon, life cycle assessment, urban sustainability, circular economy in the built environment

We confirm that we have read this submission and believe that we have an appropriate level of expertise to confirm that it is of an acceptable scientific standard.

Author Response 23 Feb 2020

David Ness, University of South Australia, Adelaide, Australia

Dear Prof Pomponi and colleagues

I feel extremely gratified and privileged to receiver your supportive, encouraging and 
constructive review.

I agree that research on Ecological Economics would be a useful means of framing my 'way forward', and will add a paragraph as suggested.

Thank you also for your insightful observation that my arguments would be strengthened by discussion and examples of strategic asset management in the global south. I have had some exposure to these challenges as a former adviser to UN on integrated, resource efficient and socially inclusive infrastructure systems.

Will be away from my desk over next few days, but will take opportunity to read further on above topics e.g. Tafazzoli re infrastructure asset management in developing countries, and Kallis et al (2012), Ropke (2005), Morgan (2017) Costanza et al (2016) and others re ecological economics. As you may know, Robert Costanza is now Prof of Public Policy at Australian National University and spoke at my university (UniSA) last week - unfortunately I missed this.

In addition, I am perusing the valuable material available through your Resource Efficient Built Environment (REBEL) Lab and am interested in corresponding further.

Hope to produce a new version of paper in about a week's time, which takes into account your comments and those of other reviewers.

With much appreciation

David

Competing Interests: No competing interests were disclosed.

Reviewer Report 19 February 2020

https://doi.org/10.21956/emeraldopenres.14490.r26599

(C) 2020 Liu G. This is an open access peer review report distributed under the terms of the Creative Commons Attribution License, which permits unrestricted use, distribution, and reproduction in any medium, provided the original work is properly cited.

\section{Gang Liu}

School of Energy Science and Engineering, Central South University, Changsha, Peoples Republic Of China

Summary of the paper

By pointing out the fact that though carbon reduced in existing buildings, the increased carbon emitted by new buildings is larger than the reduced, the topic of the article is introduced:

improved energy efficiency is far from enough, control the growth of floor area, build less or build 
nothing, should be emphasized in early stage of a project, and encouraged in the decision of investors. Several opinions are offered: the inception and planning stage of projects have a greater potential of carbon reduction than any other stage. So, the earlier, the better; for commercial buildings, it's not the bigger, the better. Instead, more attention should focus on its ability to deliver service with fewer resources input; management and stewardship of existing building stock are of great importance because of the great benefit brought by it. Also, some methods are put forward by the author based on the analysis of the above facts: focus on the building services and performance outcomes, making specific targets and corresponding time frames, control the volume of new buildings, performing carbon accounting based on consuming cities, and exerting finance on investor to consider projects' carbon emission during decision making.

Expending of the answers

1. Almost the opinion in each section is demonstrated by facts;

The author's main opinion "efficiency not enough, building less or building nothing" in detailed by the changes of floor area, building sector energy use, and direct quotation of some reports. However, there is still something to be improved: in page 9, the section "A forward way" seems to be put at an appropriate place, and overlap with the point "Development".

2. Almost data, such figures are supported by cited materials; In the article, there is reference(s) to support the figures and the sub-points. But there also exists some thing to be improved: in the section "The challenge: carbon cuts "not on track" ", the direct quotation is too much. Interpretation of these original materials, and then rearranging the language will be better.

3. Almost argument comes from fact analysis;

Indeed, arguments are based on factual analysis. However, like the question 1, there is a overlap to some degree between the section "Commercial real estate: continue to build big" and the section "Growth does not mean size", if the two parts are synthesized into one, the argument will be more clear.

4. Almost argument are summarized in conclusions.

The conclusion is on the basis of the presented argument. But the point order is random: during the argument, the order is doing it early, emphasis on service, control size, and stewardship, while the point in the conclusion is not, which also indicate the argument before the section " $A$ way forward: policies and mechanism" is not so good.

Is the topic of the opinion article discussed accurately in the context of the current literature?

Yes

Are all factual statements correct and adequately supported by citations? Yes

Are arguments sufficiently supported by evidence from the published literature? Yes 
Are the conclusions drawn balanced and justified on the basis of the presented arguments? Yes

Is the argument information presented in such a way that it can be understood by a nonacademic audience?

Yes

Does the piece present solutions to actual real world challenges?

Yes

Is real-world evidence provided to support any conclusions made?

Yes

Could any solutions being offered be effectively implemented in practice?

Yes

Competing Interests: No competing interests were disclosed.

Reviewer Expertise: 1. Energy economy;2. Geothermal energy;3. Engineering thermophysics and energy utilization;4. New energy technology.

I confirm that I have read this submission and believe that I have an appropriate level of expertise to confirm that it is of an acceptable scientific standard, however I have significant reservations, as outlined above.

Author Response 21 Feb 2020

David Ness, University of South Australia, Adelaide, Australia

Dear Prof Gang Liu,

Thank you for taking the time to review so carefully and for your insightful observations, especially about the flow and structure of the article. Your comments compel me to examine this much more.

1. 'A way forward' (page 9) may be inappropriately located in article, I was trying to use this section to emphasise that efficiency is not enough as it maintains the status quo (Shove 2017), and that stronger interventions were required including questioning of 'services', leading to the next section. But I will consider more.

In any case, the section heading probably needs changing as 'a way forward' is also used on page 11.

2. Yes, I agree that the direct quotation is too much, and it is better if I interpret and rephrase using some of my own words.

3. Thank you for valuable comment. 'Growth does not mean size' (page 10) may be better located with or integrated with ' Commercial real estate: continuing to build big' on page 8 , especially as both refer to commercial real estate (CRE).

4. 'Concluding remarks' and 'A way forward: policies and mechanisms': Concluding 
remarks were intended to highlight briefly the main points of article that you mention e.g. 'doing it early, emphasis on service, control size and stewardship' and to issue a strong rallying call for urgent action. The preceding section 'A way forward' deals with policies and mechanisms. But I agree that there needs to be a better link between 'A way forward' and 'Concluding remarks'. The Concluding remarks should at least briefly refer to the policies and mechanisms.

Thank you again for your valuable comments.

I plan to make changes to the article over the next week and issue another version. I should then be most grateful if you could please conduct a further review in the light of your comments.

Sincerely

David

Competing Interests: No competing interests were disclosed.

Reviewer Report 17 February 2020

https://doi.org/10.21956/emeraldopenres.14490.r26602

(C) 2020 Naess $P$. This is an open access peer review report distributed under the terms of the Creative Commons Attribution License, which permits unrestricted use, distribution, and reproduction in any medium, provided the original work is properly cited.

\section{Petter Naess}

Department of Urban and Regional Planning, Faculty of Landscape and Society, Norwegian University of Life Sciences, Ås, Norway

Main comments

This is a timely paper addressing an important topic that has been conspicuously underresearched in sustainability literature on the built environment. While I am generally positive to the author's attempt to direct a critical searchlight on growth in the building stock, the paper has in its present form important shortcomings that should be addressed before indexing can be recommended.

The author characterizes the paper as an 'opinion paper', and it is indeed written in a style that is maybe more journalistic than scientific, despite the high number of empirical examples and publications mentioned. According to the author, the paper uses 'philosophical conceptualization' to analyze works on the same topic, summarize their common elements, and compare differences, with a view to creating fresh insights. However, there is maybe too much presentation of examples of specific policies and strategies, compared to theoretical discussion about the 
causes of the blindness to the impacts of floor area growth.

The theoretical framework applied is theory of strategic asset management. This choice of theoretical framework appears to this reviewer as somewhat insufficient, especially since strategic asset management is often depicted as an approach to managing plant equipment and people for maximum profitability. Since such maximum profitability tends to translate into overall economic growth at an aggregate level, there is a risk of rebound effects (see, for example, Santarius et al., $2016^{1}$ ), i.e. that increasing economic surplus will be channeled into investments and activities that are not necessarily environmentally benign. The limitations of 'build nothing' and 'build less' strategies within an overall growth-oriented economy should be discussed, or at least mentioned as a challenge.

I am also missing a discussion of possible reasons why growth in consumption - of buildings as well as other commodities - is such a 'blind spot' in mainstream sustainability policies. Is there a 'growth imperative' in the prevailing economic system? If so, what are the implications for strategies of 'build nothing' or 'build less'? Without some reflection on these issues, the author's recommendations may appear a bit naïve. Here, literature within political economy (e.g. Fotopoulos, 2007²; Foster, 2011³) would be relevant supplements to the author's present theoretical framework of strategic asset management.

More detailed comments

When discussing energy impacts of buildings and building stock growth (cf. page 4), the author does not seem to include the transportation impacts resulting from the space requirements of growth in floor area per capita. In addition to the energy for heating, cooling and imbued energy in building materials, energy use for the transportation necessary to connect dwellings as well as other urban functions with each other must be taken into consideration. Ceteris paribus, urban population and job densities will be lower, the higher is the per capita floor area, and the longer will the average distances be between residences, jobs and service facilities, with increased motorized transportation and higher car dependency as a result.

On page 5, Box 1, the author writes: "China's total floor area in 2016 was approximately 58.3 billion square metres, while the floor area per capita is 28.9 square metres in urban areas and 40.4 square metres in rural areas. This compares with about 50 square metres per capita in US, Canada and Australia." Are these figures for US, Canada and Australia total floor area? If commercial floor area per capita is $25 \mathrm{~m}^{2}$, this would imply that residential floor area per capita is only $25 \mathrm{~m}^{2}$ in the USA, which seems unrealistically low compared to European countries.

A few typos/language errors:

Page 9, left column, line 4. Delete the superfluous 'the'.

Page 11, left column, line 7 from the bottom. 'net zero carbon-built environments' should be replaced with 'net zero-carbon built environments'.

\section{References}

1. Santarius T, Walnum HJ: Rethinking climate and energy policies: new perspectives on the rebound phenomenon. Switzerland. Reference Source

2. Fotopoulos T: Is degrowth compatible with a market economy?. The International Journal of Inclusive Democracy. 3 (1). Reference Source 
3. Foster J: Capitalism and Degrowth: An Impossibility Theorem. Monthly Review. 2011; 62 (8).

Publisher Full Text

Is the topic of the opinion article discussed accurately in the context of the current literature?

Yes

Are all factual statements correct and adequately supported by citations? Partly

Are arguments sufficiently supported by evidence from the published literature? Yes

Are the conclusions drawn balanced and justified on the basis of the presented arguments? Partly

Is the argument information presented in such a way that it can be understood by a nonacademic audience?

Partly

Does the piece present solutions to actual real world challenges?

Partly

Is real-world evidence provided to support any conclusions made?

Partly

Could any solutions being offered be effectively implemented in practice?

Partly

Competing Interests: No competing interests were disclosed.

Reviewer Expertise: Urban sustainability, relationships between urban form and transport, driving forces in urban development, planning theory, philosophy of science

I confirm that I have read this submission and believe that I have an appropriate level of expertise to confirm that it is of an acceptable scientific standard, however I have significant reservations, as outlined above.

Author Response 20 Feb 2020

David Ness, University of South Australia, Adelaide, Australia

Dear Prof Petter Naess,

Thank you for your thoughtful and knowledgeable review and constructive comments.

Main comments 
Yes, I wrote in journalistic style in attempt to influence policy makers by reference to their specific policies and strategies. However, I will add some theoretical discussion about the CAUSES of the blind spot and consider the reason growth in consumption is often overlooked in sustainability policies.

My experience of strategic asset management is related to the government sector, with community needs foremost rather than profitability. I accept your point about rebound effects in latter case, though, and will add some words about limitations of build nothing/build less strategies within growth economy. I also understand that surpluses and increased spending power may lead to environmentally harmful consumption and investment.

Thank you for referring me to Santarius et al (2016) in relation to rebound effects, and Fotopoulos (2007) and Foster (2011) also help understanding of 'degrowth'. I have viewed 'growth' in terms of social and environmental ends, not as material growth and accumulation. Conversely, I concur with Santarius et al $(2016,4)$ that degrowth aims to achieve "more just distribution of economic welfare" and "a substantial reduction of environmental pressure".

\section{Detailed comments}

Agree with transportation impact resulting from growth in floor area per capita. I am focusing on office buildings rather than residential, but similar impacts may apply.

Thank you also for detecting my error in Box 1 on page 5, where I incorrectly summarised work of Yan (2018). This should read: China's total floor area in 2016 was approx. 58.3 billion $\mathrm{m} 2$. The residential floor area per capita was around $28.9 \mathrm{~m} 2$ in urban areas and $40.4 \mathrm{~m} 2 \mathrm{in}$ rural areas, compared with about $50 \mathrm{~m} 2$ in US, Canada and Australia (that of most OECD countries was about $40 \mathrm{~m} 2$ ). My words regarding commercial floor area accurately reflected Yan's i.e. average commercial floor area per capita in China is $8.5 \mathrm{~m} 2$, while that in US is above $25 \mathrm{~m} 2$.

Thank you also for mentioning the typos/language errors. I will add to and correct the article after receiving comments of another reviewer.

With appreciation again

David Ness

Competing Interests: No competing interests were disclosed. 